\title{
A HETEROGENEOUS CHARACTER - OPERA, CIRCUS AND KITSCH IN FILIP BAJON'S FILM ARIA FOR AN ATHLETE
}

IZABELA TOMCZYK

Faculty of Humanities,

Cardinal Stefan Wyszyński University in Warsaw

izatomczyk@interia.pl

Aria for an Athlete (Aria dla atlety, 1979, dir. Filip Bajon) is the life story of Władysław Góralewicz - a wrestler who went from being a circus strongman fighting for the enjoyment of the audience to become a real champion. At the same time, Bajon uses his film to introduce the viewer to reflections on the meaning of art and its relationship with kitsch. The main character moves within two spectacles that remain polar opposites - the opera and the circus. While the status of the former is firmly established and allows it to be assigned to the sphere of elite art, the status of the latter is highly questionable - the circus is classified as a phenomenon from the area of mass culture. However, Bajon is not interested in the differences between these spectacles, but focuses primarily on the web of inseparable links between them. He does not establish a rigid borderline between the categories of kitsch and art, either, since - in his view - it often becomes blurred. The director notes that each form of art goes through a kitsch phase, and at the same time, something that comes from kitsch can become a starter for art.

Trying to take a closer look at the connections between the opera and the circus, as well as art and kitsch, I will focus primarily on the construction of the three protagonists of the film. I have the impression that their mutual relations reflect the complicated relations between the above-mentioned forms of spectacles, as well as between art and kitsch. Góralewicz, Max the clown and the tenor Baptisto Messalini are, on the one hand, carriers of the characteristics of the worlds to which they belong, and on the other 
hand, elements of their construction tend towards a cultural space that is completely alien to them.

\section{DECLINE}

In their analyses, the film's interpreters (Basiaga 1979; Kłoporowski 1979; Ochalski 1979; Zwaniecki 1979; Kornatowska 1990, Nurczyńska-Fidelska 2003) paid close attention to the way in which the filmmaker decided to create a picture of fin de siècle, the era of decadence. Bajon's artistic decisions are indeed worthy of interest in this aspect. However, what I would like to look at the beginning of this text is the issue of the decline - an important idea for the construction of the protagonists and also for the whole film, which we watch from the perspective of the end of life experience. The feeling of an approaching end is constitutive for the decadent worldview, but it also plays an important role in the relationship between art and kitsch.

The film begins with a scene in which Góralewicz writes a letter to the editor of a newspaper, wanting to interest him in the idea of handing over to the opera a collection of sculptures which are his reminders of the triumphs he enjoyed in the arenas around the world. It is 1937. Góralewicz is a very old man, summarizing his life at the end of it. The gift for the opera is an important element of his life balance, it becomes a form of paying homage to the art that has attracted him throughout his life. Góralewicz wants to transfer the collection during the benefit performance by tenor Baptisto Messalini - a person who had played an important (though not necessarily positive) role in the life of the wrestler, becoming a kind of embodiment of the opera The benefit shows that the tenor - just like the wrestler - is at the end of his life and also reassuming his own achievements.

The decline and the end of life are the existential context for the key considerations contained in the film. However, it is not only the protagonists who are 'at the end'. In the interview with the newspaper editor, who, intrigued by the letter, comes to see Gorralewicz, the wrestler twice repeats: 'Opera died tonight'. The power of this statement is all the stronger because it does not result directly from the circumstances of the ongoing conversation, but rather it is a reflection made in the context of reflections on the past. The editor's visit becomes the springboard for the wrestler's story about his life and the era in which he has lived. Artur Hutnikiewicz calls the complicated 
time of fin de siècle an era clearly declining and predisposed to extinction (see: Hutnikiewicz 1994: 27). The scholar characterizes this period as, on the one hand, a time of great achievements and grandeur, but on the other, he also points out the emerging impotence, exhaustion and fatigue, causing this era 'to be questioned as a system, as a certain social, political and moral order, as a certain theosophy, concept, vision and program of life' (ibid.: 14). Teresa Walas (1986: 44), on the other hand, defining the characteristic elements of the decadent worldview, mentions the 'idea of the decline' as one of the main themes undertaken at the turn of the century and links the sense of decadence with a specifically understood evolutionism that combines creative and destructive elements and adds that this evolution must be 'fulfilled, and the fulfillment means a decline and an end towards which humanity, social formation, race and civilization are heading' (ibid.: 45). Perhaps Góralewicz noticed such exhaustion and fatigue, as well as the way to inevitable death, in the recollections of the time of his youth? By its very nature, opera - the source of the values that guided those times died with illusions and youthful naivety.

Marek Basiaga (1979: 29) suggests that the sentence 'Opera died tonight' should be read literally. The researcher notes that 'As the culmination form of bourgeois culture, opera was giving way to other forms of spectacle. The words about its death are here, in a way, a literal formula for it leaving the first ranks; this role is taken over by the cinema.

The moment when we meet Góralewicz - the beginning of 1937 - is also a decline. Soon a war will break out, the experience of which will re-value the entire culture and social relations in Europe. I have the impression that Bajon has included in his motion picture a premonition of the approaching catastrophe, the approaching end of the current world. The first frames of the film gradually reveal a chaotic room, as if deserted in a hurry. Off camera, we can hear the rattling of a typewriter and Góralewicz's voice reading his letter to the editor. The layer of image and sound designed in this way allows us to guess that the presented space is the editorial office of a newspaper. But why is the room deserted? Perhaps this is what it will look like in a few months, when only bomber air raids will be heard? The camera shows the view outside the window: a neon sign that reads 'Paradise' above the entrance. Is it the Cinema A cut. Now we approach a similar neon sign, but this time it is on the stage. Off camera, before we see the tenor, we can 
hear the aria 'Pazzo son guardate' from act three of Giacomo Puccini's aria Manon Lescaut. The camera tilts down a bit and we see a singer dressed in a red dressing gown and a shaggy wig. The man is singing to an empty room. A group of dancers dressed in tailcoats appears behind his back. The only spectator of this scene is Góralewicz, who watches leaning against the door. 'Opera died tonight', he later sums up what he saw. 'It died, reduced to a vaudeville piece sung in a bathrobe in a cinema hall'.

This is the key statement, the formula proclaiming the twilight of the known shape of the world on all possible levels. It means the end of the era, the end of life, the death of high art, which, with its last breath, one last desperate aria, tries to win itself a tiny place in the space annexed by mass spectacles.

Andrzej Osęka writes about kitsch in the introduction to the Polish edition of the monograph by Abraham Moles (1978: 6): 'Thus, kitsch would be an imitation of art, its simplified, absurdly vulgarized copy. The downfall phase of any style would inevitably tend towards kitsch from the moment when newly created works are only a pale imitation of the prototypes'. Moles himself, trying to answer the question of what kitsch is, explains that this concept is related above all to the period in which a new style is born, a new aesthetic is created. Kitsch is combined with 'stylelessness', with a certain luxury built over traditional functions, and also with a certain, though not too great, dose of naivety' (Moles 1978: 13). The year 1900, which is the peak moment of the development of bourgeois culture, is important in Moles' reflections on the 'genesis of the kitsch system' (ibid.: 137).

The idea of decadence, clearly displayed in the Aria for an Athlete, gives the director the opportunity to introduce the category of kitsch to the artistic discourse in order to check how it is shaped in relation to art. It is also significant how strongly emphasized the beginning of the year 1900 was by the artist - on the first day of that year, Góralewicz will fight one of his fights and then, for the first time, will find delight in opera singing. At the level of meaning, it is the first important confrontation of art and kitsch - the opera aria with the wrestling fight. The day before, for the first time in his life, Góralewicz will face the new vision of the world, the 'kitsch system' in a brutal way. It is New Year's Eve 1899; the wrestler arrives in Charlottenburg. Góralewicz, dressed in a tailcoat, goes out into the streets of the city in search of the Adler hotel. His guide is an old man wearing 
a light-colored top hat and a checked jacket. This outfit is reminiscent of a dandy, but at the same time the physiognomy of the old, toothless man appears at odds with the original association. The guide leads the wrestler into the night streets: 'The world is ending, the comet is coming, the $19^{\text {th }}$ century is almost over. (...) Follow me, I will show you... Etwas wunderlich. Only this night, at the Two Dragons, only for the mad, only for the mad'. In the distance, an animal tamer in a costume resembling an owl appears on the street and blindly snaps his whip. Out of the brothels, whose stairs run straight into the observed street, come prostitutes. Two wrestlers - one wearing an Austrian helmet and the other wearing a Chinese red cap - fight each other like roosters. Armed with a saber, a man in a white gala uniform grapples with a wrestler holding an axe in his hand. The whole bizarre scene is accompanied by the animal tamer's laughter and poignant music. 'I can't look at it. Tell me when it's over', Góralewicz says to his guide.

In an interview with Kino, the director explains the scene:

(...) when I was making the sequence of Góralewicz's coming to Charlottenburg, I knew that it would be a sequence about emptiness, about a man in an empty city, and I tried to guide it in such a way that things would become clear and expressive. Not because Góralewicz himself would talk about his alienation, but by showing a man who cannot cross the border of alienation that is created around him. I am not thinking here of metaphysics, but of the alienation of a man in a particular culture, which he does not know and which he cannot 'domesticate', accept, which he does not understand and, therefore, cannot enter into it (Mruklik 1979).

Both the old man and the world to which he introduces the wrestler are a lie, they try to be a parody of dandyism and the circus ${ }^{1}$. However, a parody is a form of repetition that requires ironic and critical distance, thanks to which differences and not similarities become visible 2 . The old man in the top hat takes himself seriously. He superficially uses elements that have become conventions, thus creating a kitsch space. The new world,

1 The combination of these two aesthetics - dandyism and the circus - is not accidental: both are based on masks, so they remain at a symbolic level. See: Sznajderman 2014.

2 I use this understanding of parody after: Hutcheon 1986. 
the world of a new era, into which Góralewicz is introduced, is the world in which kitsch has spread.

The declining world created by Bajon is 'looked after' by two cinema artists. As Maria Kornatowska (1990: 223) notes:

The spiritual and artistic patrons of Aria for an Athlete were two masters of the screen spectacle, poets of the 'twilight of the idols' and decadence Federico Fellini and Luchino Visconti. The opposition of two forms of the old performing arts: the plebeian circus (Fellini!) and the courtly melodrama (Visconti!) had a clear sense. Góralewicz was a wanderer, like all circus people, the opera building was a fixed point, standing like a distant home for a tired wanderer.

And at the same time:

Signs of crisis and disintegration in the womb of this effusive world are visible from the very beginning, from the first scenes. One could say that Góralewicz broke into a palace, which tempts and attracts with numerous beauties, but imperceptibly is collapsing into ruin (ibid.: 223).

\section{THE CIRCUS SPACE AND MAX THE CLOWN}

Ewelina Nurczyńska-Fidelska (2003), similarly to the above-mentioned Kornatowska, describes the space of the circus in Aria for an Athlete through the prism of Fellini's films. According to the researcher, Fellini's films are both a source of inspiration and a declaration of Bajon's artistic identity. The director introduces his protagonist to a circus filled with 'figures of clowns, acrobats, strongmen, 'freaks' created by the nature' (ibid.: 70). It is a travelling circus for the common people, the same as the viewer could observe, for example, in La Strada. Zampanò's strongman shows were based on ripping apart chains, the main attraction of Siedelmayer's circus, where Góralewicz goes, are the fake wrestler fights. The owner of the circus, in order to make a profit, enters makes a deal with bookies. According to Bogdan Danowicz, such manipulations were a common occurrence in circuses that performed in the provinces. Victory was not determined by skill, but by name, money or clear instructions from the owner. It is significant that the audience naively and stubbornly believed in the reality of the fights (Danowicz 1984). Siedelmayer is aware of this faith and that 
is why he instructs Góralewicz: 'You can't finish the fight after ein minute because they have paid for ten minutes and they won't want to lose bets after one minute'.

The circus director prepared a life story for each of his performers because 'everyone must have their own story'. He tells these stories each time he enters a town - in this way he opens up his world to the viewers. What is striking about these stories is their absurdity and cultural incoherence. One can see in them a peculiarly transformed myth of the werewolf, which in Siedelmayer's version is a woman. The smallest man in the world is stylized not so much to resemble the dwarfs painted by Diego Velázquez, but the artist himself, who makes a long journey like Odysseus. The king of Greenland brings to mind the biblical Samson, whose fate has strangely intertwined with that of Lot's wife. The androgynous figure resembles a mythical centaur. According to the classification proposed by Paweł Beylin (1975), these figures, as well as their stories, are an example of market kitsch, which processes patterns derived from both mythology or broadly understood high culture, as well as from folklore for its own needs. The idea of creating 'one's own history' comes from Romantic artists who started the act of creation from themselves. However, the Romantic artists wanted to be authentic, while Siedelmayer, both in setting up fights and in inventing stories, which he imposes on the circus performers as their own, perpetrates a fraud. Thus, he is a creator of art which Maria Poprzęcka (1998: 224) - transferring reflections on kitsch from the space of aesthetics to the ground of ethics calls evil:

The evil inherent in this art is, therefore, falsehood above all else. It is a denial not of art, but of truth. Much is said about the fact that bad art serves to deceive people and that they want to be deceived. This is only right in relation to the compensatory function of art. No one though agrees to falsehood. Kitsch customers take it seriously and 'really'. For them kitsch really is art.

In opposition to the circus spectacle, the rules of which are defined by kitsch, Bajon created a different kind of circus, closely connected with the everyday life of people who greate it with their hard work, but also with poverty and longing for a better existence. This circus is described in Wolfram's Aria to the Evening Star in act III of Richard Wagner's opera 
Tannhäuser, sung by Popov. Faithful to his friendship with Tannhäuser, Wolfram conceals his love for Elisabeth. The Aria to the Evening Stat is the expression of his love and longing. Tannhäuser, on the other hand, despite the fact that his love for Elisabeth is mutual, cannot free himself from the sinful love for Venus. The possessive goddess, deaf to the knight's requests, does not want to free him from her influence. An analogous motifthe intertwining of longing for something great with the search for love and indifference of the goddess - is present in Baudelaire's The Fool and Venus, whose protagonist is a jester, and in The Old Mountebank. Just as Tannhäuser, entangled in impure love, meets with a general condemnation, so the jester, condemned ex natura for his lechery, is excluded from the familia Christi (Baudelaire 2008: 13).

Baudelaire's jester combines the figures of Tannhäuser and Wolfram, but by singing his song, Popow transfers their fate to that of his companions. Cyklop and Bolcio - Góralewicz's closest friends - wish to break free from the world of Siedelmayer and dream of starting their own circus. However, they are not given the opportunity to make this dream come true. The former dies, completely blind, in a shelter for the homeless, the latter loses his life as a result of another reckless bet. Their story reflects the fate of the mountebank - 'stooped, frail, decrepit, a ruin of a man' (ibid.: 2008) who, in complete loneliness, lives out his last days in extreme poverty. This tragic figure complements the picture of the circus as a source of entertainment, mass art, but also bad art, kitsch.

The wrestler is not a figure who is fundamentally connected with the circus. It is rather the clowns, tightrope walkers and animal tamers who make up the basic cast of the circus shows. So, too, must a clown appear in Bajon's film. The figure of Max the clown has no direct influence on the main narrative, but it is because he appears outside of the plot and the spectacle that he seems to me particularly significant and multidimensional - in a way, embodying the definition of the circus in Bajon's approach.

Max the Clown carries mystery and longing within him, just like Wolfram's song conceals mystery and longing. He carries sadness completely opposed to his profession - like the jugglers from Paris Spleen or Gelsomin from La Strada. He silently watches and listens to Góralewicz's conversations with Abs, Bolcio and Cyklop. It is significant that Max does not resemble a circus clown. He is dressed as Pierrot - in a black skullcap and 
a loose white outfit with red diamonds. According to Monika Sznajderman (2014: 25), the clown's costume is a symbolic element of the chaos from which the clown was created: 'The earliest model of a jester's costume stood out with a multitude of irregularly arranged patches of various colors. This trait of the outfit corresponded exactly to the original nature of clown and harlequin: trickster, amorphous, chaotic'. The researcher adds that when the jester's costume begins to be dominated by geometric and arranged shapes and his behavior takes on balance, subtlety and sophistication, then 'we are already witnessing the symbolic process of the emergence of the cosmos from chaos, the process of crystallization of the cosmic order; the sealing of the ongoing act of creation of the world in miniature' (ibid.: 26-27). Thus, the symbolic world that Max brings with him is a world of orderly chaos - a world from which culture and civilization emerge. However, the clown's creation is burdened with ambiguity: 'for it can mean creativity ascending to the heights of genius, expressed by the image so liked by the Romanticists of a tightrope walker jumping up into the sky, or creativity understood as negotiating with the powers of the underworld and opposing God's intentions' (ibid.: 34). In our case, creation rebelling against God is the art of evil - it is kitsch.

Max's appearance refers to commedia dell'arte, which, after all, has in its history tawdry fair periods and times of rubbing against kitsch. At the same time, as Margot Berthold (1991: 451) notes: 'Commedia dell'arte is the source of a nutritious ferment. Whenever theatre, at any latitude, becomes mired, until it loses its breath, in a tangle of well-worn conventions, this timeless form of stage play always comes to its aid and has a reliable stimulating effect'. Commedia dell'arte is, as it were, the core of acting - improvised on the spot, deprived of literary rigor, it becomes a space of actor's freedom.

Improvised comedy was born in the 16th century and survived as a theatrical genre until the early 19 th century. Max, whose father is Jean Gaspard Deburau, is brought to life in his new, changed form in the first half of the 19th century. He is thus the one who, on the one hand, says goodbye to his home environment (the world of commedia dell'arte) and, on the other hand, welcomes the upcoming new spectacle - film. The degree of improvisation - which the burlesque actor learned from an actor of Italian comedy - was similar in both shows (see: Skrzypczak 2009). And just like commedia dell'arte, the film had to rise from the level of tawdry kitsch. 
Bajon reminds us of this stage, weaving into the picture a recurring motif of the cheap 'Paradise' neon sign, stylizing Góralewicz's narcotic visions like silent cinema, or introducing a scene with Breitkopf making films solely because of the high chance of earning money. However, at a certain point in its history, the film transformed from cheap entertainment into a narrative spectacle, the primary aim of which is no longer to entertain and amaze the viewer, but to drag him into a diegesis.

Just like the spectacles Max helps to create - the circus, commedia dell'arte, film - his status is ambiguous. Karolina Charewicz-Jakubowska (2010: 45-46) characterizes the figure of the Pierrot thusly:

The Pierrot of the mid-19th century combines the features given to him by Deburau and the physiognomy of Gilles from paintings by Jean-Antoine Watteau, who was rediscovered at that time. The ephemeral figure is filled with innocence and dreamlike detachment from the surrounding world; the Pierrot figure becomes an alienated, peripheral figure, interpreted as the mask behind which the artist hides - 'a tired, melancholic soul, caught in the trap of the world of economic greed'. The loss of innocence is the price that Pierrot pays for entering the period of intensive industrialization and urbanization of the second half of the $19^{\text {th }}$ century. The mask remains, the face still freezes in mimic expressions, but they hide new emotions.

Behind this mask there is already a Pierrot of the fin de siècle with the characteristics of a drunkard and a sadist who deliberately breaks cultural, social and political norms. Max does not reach this border, he decides to remain in the 19 th century. He tries to escape from the world - or, according to his nature, remains on its outskirts - and becomes a porter at the Adler Hotel - the very place where the opera world was having fun on New Year's Eve in 1899.

How does Góralewicz find himself in this dual world - of tawdriness and kitsch on the one hand, and of high culture on the other? The wrestler seems to function somewhere on the borderline. He does not want to agree to the arrangement proposed by the director. He wins a fixed fight and recites a fragment of Friedrich Schiller's The Glove to surprised spectators, shouting the line about a lion entering the arena. This fragment takes on a new meaning - the story of the knight and the lady and its unexpected ending is no longer the most important, the arena and the lion that will fight 
in it are important. It is Góralewicz who is the lion and the recited verses of the romantic piece become a kind of announcement of his further fate. High art is supposed to define his existence.

The wrestler collects sculptures throughout his life. It is significant that these are sculptures of one figure - Atlas holding the Earth. However, their aesthetic value does not matter much. Bajon emphasized in an interview (Mruklik 1979) that it was important for him where his protagonist got the first of them - Góralewicz stole it from George Hitzler's luxury car. According to the director, this is a deed that testifies to the protagonist's attempt to cross the border of the world he did not belong to but which he missed. Hitzler himself calls it 'the great world': the world of women in black gowns, opium, strength and... opera. Thus, to some extent, it is also the world of high art. Góralewicz, longing for this world, trying to cross its border, rubs against kitsch - this is how his collecting passion could be seen ${ }^{3}$. The huge amount of the accumulated objects mercilessly exposes the protagonist's loneliness and futile attempts to prove himself that he can do everything.

This evidence and the desire for high art to shape his life brings him closer to that of a contemporary artist and leaves him on the borderline. Sznajderman (2014: 217), writing about the relations between clowns and artists, notes:

A contemporary artist, just like a romantic juggler-artist, becomes the master of his imaginary worlds - he becomes a magician, another God. However, whilea divine being, he is also just a circus prestidigitator, who pulls his worlds like a rabbit from the sleeve in order to replace them with new ones, with the belief that the only sense of the world is the multiplication of all possible combinations.

\section{THE WORLD OF OPERA AND THE KITSCH OF THE TENOR BAPTISTO MESSALINI}

'The opera died tonight,' said a girl on the first day of the year 1900 to the tenor Messalini sitting in the circus arena in Charlottenburg. The same words were repeated several decades later by Góralewicz. On that day, however,

3 I am thinking here of the 'kitsch attitude' which A. Moles (1978: 40) distinguished among the types of relations between humans and their surrounding. 
on the first of January 1900, the opera was born for him. He heard an opera aria for the first time and became enchanted by $\mathrm{it}^{4}$.

The group from Westman's circus announces the death of the opera in a symbolic moment - on the day of the end of the era, the end of the century ${ }^{5}$. Another thing is that the opera tenor sits together with them in the audience. The second half of the $19^{\text {th }}$ century was the moment when opera in the form of a musical drama achieved its goal. The achievements of Modest Mussorgsky, Richard Wagner and Giuseppe Verdi brought this art to the top of its ability to influence the viewer: the content and musical form blend into one perfect work. Meanwhile, in the film, this great world of opera has come to enjoy such a low-brow spectacle as wrestling fights!

In reaction to the sentence uttered by the girl, Messalini stands up and starts singing the aria 'Vesti la giubba' from Ruggero Leoncavallo's Pagliacci. Its protagonist, Canio, who is the head of a troupe of actors playing the commedia dell'arte, has just learned that his wife is cheating on him. Furious and desperate, however, he must prepare to play a comic role. The aria describes his situation: he is a clown, an actor who has to go on stage despite being tormented by his feelings. Canio in his aria is sincere. Messalini entered a game with those in the audience. His performance of the dramatic 'Ridi Pagliaccio' made it sound grotesque, false, it was calculated to achieve a certain calculated effect, a dilettante experience like kitsch. But at the same time the aria sung in such a way - this specific aria - reveals his nature, the nature of a jester. All the more so because in his film, Bajon tells him to sing another aria: La donna è mobile from Giuseppe Verdi's opera Rigoletto, in which the title character is the duke's hideous jester, hated by everyone. Messalini wants to draw Cecylia's attention and seduce her with his singing. Just like in Westman's circus, here too, the tenor treats truth and art as objects - he imitates it, uses ready-made clichés, wants to produce an effect without any content inside.

4 The patron of this part of the film - as Nurczyńska-Fidelska (2003) rightly points out - is Visconti.

${ }^{5}$ Researchers do not agree on the date of the 'death of the opera'. Mladen Dolar (2002) shifts this moment a few years forward - to the beginning of the $20^{\text {th }}$ century - although he accepts the general assumption that the last great operas were created around 1900. 
In the circus space, Siedelmayer is the bearer of kitsch attributes. The opera is marked with kitsch by Messalini - a poser, a show off who hangs his photographs on the wall, and for fear of hoarse voice ties wears a white fur stole around his neck; a clown that becomes the alter ego of Max, the good Pierrot. Considering this relation from the perspective of the jester's birth myth, we can see the process, characteristic for each artistic era, of returning to its origins in the duality of 'Max the clown - Messalini the singer'. As Sznajderman (2014: 26) writes:

As soon as the representatives of the next generation of jugglers gradually gained genteelness, and their costume - elegance and harmony, there immediately appeared next to them figures referring anew to the mythical first period through their costume, clumsiness, roughness and churlish behavior.

It is no coincidence that this tenor wears a white fur stole - the clown is a figure from the borderland of nature and nurture ${ }^{6}$, and while Max the Pierrot remains closer to nurture in his dual being, Messalini tends towards nature.

The arias sung by Messalini fit into my reflections on the spectacles, the birth of which was accompanied by a clown, a Pierrot. By incorporating this unclear figure into its structure, opera itself takes on an aesthetically ambiguous character. Opera - elite art - reveals its fascination with the circus - mass art - and flirts with it. This dualism is also visible in case of its reception. Mladen Dolar (2002) reminds us that contemptuous statements about the opera were particularly frequent in the $18^{\text {th }}$ century. They created then almost a separate genre of literature. Opera works aroused extreme emotions - they became 'cursed works' only to enter the canon of the most outstanding cultural achievements years later. In the film, Bajon evokes two works that caused scandals on the day of their premieres. In the scene of the fight between Góralewicz and Abs, a musical motif from Verdi's La Traviata appears - the toast 'Libyamo, ne'lieti calici' from the beginning of the opera. The second piece is more subtly marked. In the scene where, after a fight in Westman's circus, Góralewicz ends up in

${ }^{6}$ The remains of this dualism are, for example, rooster crests appearing in the clothes of clown figures. 
the Adler Hotel, the protagonist browses through a book. This is Salome, the edition of Oscar Wilde's drama, with Aubrey Beardsley's drawings. When Richard Strauss saw the staging, he decided that the drama was an excellent material for an opera.

Just as Siedelmayer introduces the circus into the space of kitsch and Max the clown elevates it into the area of art, so does Messalini the tenor degenerate the beauty of the opera to the level of kitsch, while the one who liberates it is Góralewicz.

'Everyone talked about me being 'a mountain of meat', and somehow nobody noticed my good manners', says Góralewicz to the editor when his story comes to the preparation to go out in search of the Adler Hotel in Charlottenburg. Indeed, against the background of the poor dosshouse, his tailcoat looks chic. When Westman announces his fight with Władysław Prochaski, he refers to the wrestler as an 'artist-athlete'. The dualism of nature versus nurture is visible in the character of Góralewicz'. His physical strength and his profession belong to nature. The element of nurture, on the other hand, is his faith in the opera. The strong tension between the two elements can be seen in the fight against Prochaski. Góralewicz listens, enchanted, to the aria sung by Messalini, and at the same time fights, but he no longer wants a physical victory over his opponent, but to bring the fight to an end as soon as possible and be able to listen to the aria in peace. The 'mountain of meat' was defeated by the opera. The protagonist openly admits this love, as well as his faith in the opera, in his conversation with the editor. This feeling turns out to be stronger than the bitterness about being cheated on by his wife.

In the context of the description of Gorralewicz's nature, as well as his relation to the opera, the last battle that Góralewicz fights with the older Abs is important. Abs fights very brutally, wrestling freestyle. Góralewicz, dressed in the tailcoat which he wore to the opera performance, adheres to classical rules. It is only when he is in danger of failure that he takes on the rules imposed by his opponent and wins. The tailcoat, combined with the brutal, violent clash with Abs emphasizes the dual nature of the film's protagonist. Góralewicz leaves the ring, straightening his ripped clothes.

7 The conflict of nature versus nurture, which in the case of Góralewicz will become even more pronounced during the fight against Abs, is characteristic of the decadent view of the world. See: Walas 1986: 63. 
The picture is complemented by Cavaradossi's aria E lucevan le stelle from Puccini's Tosca. The protagonist sings, waiting for the execution that will take place in a moment. In his mind's eye, he sees his happy life to date and the figure of his beloved Tosca, a singer.

Góralewicz is similarly condemned - he broke the rules in which he believed, the element of nature won with the element of nurture. Ragged and bloody, he heads towards the opera. Suddenly, what he sees changes everything. Góralewicz walks through a large fountain located opposite the opera house, immerses himself in water and gazes at the Pegasus on top of the building. Off camera, we hear the last lines of the aria.

The opera cleansed Góralewicz, but he also allowed the opera to return to its rightful place, in a way. The element of nurture did not disappear in Góralewicz. The waters through which he passed and which cleansed him are the waters of Hippocrene, the legendary spring of the muses. Pegasus, who so caught his eye, is a symbol of immortality, but also of poetic inspiration. On the other hand, Góralewicz's faith in the opera meant that its embodiment was no longer the kitsch Messalini - the opera now took the form of Tosca.

Beylin (1975: 214-215) notes that in terms of aesthetics, kitsch is subject to the same rules as art:

The informative role of art, which (...) underlies its aesthetic value, also affects the whole problem of kitsch. But kitsch is by no means a simple reversal of art. Its relation towards works considered valuable is much more complicated. Kitsch is not a simple reversal of art due to the fact that it belongs to the world of art itself. (...) Kitsch, if we disregard valuation, after all, performs all the functions of a work of art, for many viewers it is simply $\operatorname{art}^{8}$.

According to the scholar, kitsch is an important argument used in artistic disputes, and thus becomes an internal problem of art. It is, therefore, not possible to apply aesthetic criteria to separate the pure features of kitsch

8 Abraham Moles (1978: 13-14) sees the inseparability of art and kitsch in a similar way. 
from the pure features of a work of art not being kitsch. What then remains for the artist?

Maria Kornatowska (1990: 225), analyzing Bajon's film, writes:

Bajon likes to juggle quotations, reminiscences and associations. Here are the wandering jugglers from La Strada (1954), here is the beach from Death in Venice (1971), a crazy banquet from Sweet Life (1960). Here is a unique setting of the camera, an unusual movement (the famous vertical shot from Citizen Kane, repeated by the director entering the professional ranks), here is an unparalleled composition of the frame, the concept of decoration, lighting, makeup. Fellini and Visconti created a pattern of brilliant kitsch on the screen. In Bajon's notion, it defines the essence of cinema, it soul artificiality and kitsch.

The director himself, telling the story of his experience in making the film, admits that he always had a feeling of balancing on the edge. In his opinion, the poetics of kitsch is an element of art, as long as the artist sensitively avoids what is unacceptable in a work of art (Mruklik 1979). The director did not allow this to happen, if only because of the specific construction of the protagonists, whom he allowed to function both in the world of kitsch and in the world of art. Max the Clown ennobles the circus kitsch, but also brings with him the duality of the nature of commedia dell'arte and film. Góralewicz, the artist-wrestler, although he comes from the world of the circus, longs for the opera. Messalini the singer, who by virtue of his profession should be a creator of high art, liberates kitsch. Bearing traits of both of these worlds, the characters become multidimensional, ambiguous, create a space in which kitsch and art illuminate each other again. This allows us to find values that are not visible when we apply only aesthetic criteria specific to a given field of art (see: Poprzęcka 1998).

\section{Bibliography}

Marek Basiaga (1987), Opera umarła dziś w nocy, „Kino”, No. 2.

Margot Berthold (1991), The History of World Theatre: from the Beginnings

to the Baroque, transl. E. Simmons, New York: Continuum.

Paweł Beylin (1975), Autentyczność i kicze, Warszawa: PIW.

Charles Baudelaire (2008), Paris Spleen and La Fanfarlo, transl. R.N. Mackenzie, Indianapolis: Hackett Classics. 
Karolina Charewicz-Jakubowska (2011), Odejście pierrotów. Siegfried Kracauer i moc przypadku, „Przegląd Kulturoznawczy”, No. 2.

Bogdan Danowicz (1984), Był cyrk olimpijski..., Warszawa: Iskry.

Linda Hutcheon (1986), A Theory of Parody. The Teaching of Twentieth Century,

Durham: Duke University Press.

Adam Hutnikiewicz (1994), Młoda Polska, Warszawa: PWN.

Krzysztof Kłopotowski (1979), Słodki owoc dekadencji, „Literatura”, No. 43.

Maria Kornatowska (1990), Wodzireje i amatorzy, Warszawa: WAiF.

Abraham Moles (1978), Kicz, czyli sztuka szczęścia. Studium o psychologii kiczu, transl. A. Szczepańska, E. Wende, Warszawa: PIW.

Barbara Mruklik (1979), Każdy musi mieć swoja historię. Rozmowa z Filipem Bajonem, „Kino”, No. 11; available on-line: http://akademiapolskiegofilmu.pl/

pl/historia-polskiego-filmu/artykuly/kazdy-musi-miec-swoja-historie/406. Ewelina Nurczyńska-Fidelska (2003), Czas i przesłona. O Filipie Bajonie i jego twórczości, Kraków: Rabid.

Andrzej Ochalski (1979), Atlas w „pięknej epoce”, „Kino”, No. 12

Maria Poprzęcka (1998), O złej sztuce, Warszawa: WAiF.

Piotr Skrzypczak (2009), Aktor i jego postać ekranowa. Aktorstwo ery kia niemego w teorii i refleksji krytycznej, Toruń: Wydawnictwo Naukowe UMK.

Monika Sznajderman (2014), Błazen. Maski i metafory, Warszawa: ISKRY.

Teresa Walas (1986), Ku otchłani: dekadentyzm w literaturze polskiej 1890-1905,

Kraków: Wydawnictwo Literackie.

Andrzej Zwaniecki (1979), Dekadencki fotoplastikon, „Tygodnik Kulturalny”, No. 48 Slavoj Žižek, Mladen Dolar (2002), Opera's Second Death, New York - London: Routledge.

\section{Summary}

Analysing Filip Bajon's film Aria for an Athlete, the author focuses on the relationship between opera and circus, paying attention primarily to their interrelationship and not the differences. According to the author, the category common to both types of performance is kitsch. Any kind of art has in its history a phase of kitsch, yet what is derived from the kitsch can become the beginning of art. While describing the coexistence of opera and circus, the author makes a study of three characters in the film: Władysław Góralewicz, Max the clown and the tenor Baptisto Messalini. In her opinion, 
these representatives of the world of circus and the opera, respectively, have a number of attributes that allow to assigning them the culture which is alien to them. Max, a circus clown, elevates kitsch, but also shows a duality of nature of both commedia dell'arte and film, Góralewicz, the artist-wrestler rooted in the circus, longs for the opera, the singer Messalini, whose profession is to create culture, brings kitsch to life.

Keywords: Filip Bajon, circus, clown, opera, wrestling, decadence, parody, kitsch 